\title{
SYNTHESIS OF POLYANILINE MICROCELLULOSE COMPOSITE
}

\author{
Lela Mukmilah Yuningsih ${ }^{1}$, Dikdik Mulyadi², Devia Indriani ${ }^{3}$ \\ Departmen of Chemistry, Faculty of Science and Technology, Universitas Muhammadiyah \\ Sukabumi, Sukabumi, 43113, Indonesia. \\ E-mail: lelathea@ummi.ac.id
}

Received : 18 Juli 2020; revised : 20 Agustus 2020 ; accepted : 8 Maret 2021

\begin{abstract}
ABSTARCT
SYNTHESIS OF POLYANILINE MICROCELLULOSA COMPOSITE. In this study, the Polyaniline-Microcellulose composite was produced as a solid electrolyte. In the previous research, polyaniline-cellulose composite has been carried out. However, the electronegativity and electrical voltage are still below the conventional batteries. In order to increase its performance, a polyaniline-microcellulose composite was synthesized. The purpose of this research is to determine the effect of the Polyaniline-Microcellulose composite on its conductivity and voltage values. Microcellulose synthesis used a combination method of sulfuric acid hydrolysis with concentrations of $30 \%-64 \%$ and sonication. Polyaniline - Microcellulose composite was synthesized via polymerization of aniline using chemical oxidation and sonication. Microcellulose was characterized using particle size analyzer (PSA). Microcellulose and PANI-microcellulose composites were characterized using FTIR, SEM-EDX, and XRD. The conductivity values and electrical quantities of PANI-Microcellulose composite were measured using LCR-meter and Digital Multimeter, respectively. The diameter of the microcellulose particles were between $20 \mathrm{~nm}-40,6 \mu \mathrm{m}$. Microcellulose and PANI-Microcellulose composites showed identical absorption bands, namely the stretching vibrations to- $\mathrm{OH}$ and $\mathrm{CH}$ (aliphatic), which were shown at wavelengths $3444.87 \mathrm{~cm}^{-1}$ and $2897.08 \mathrm{~cm}^{-1}$, two typical groups of cellulose. The typical groups of PANI are bending vibrations from $\mathrm{N}-\mathrm{H}$, stretching vibrations of $\mathrm{C}=\mathrm{C}, \mathrm{C}-\mathrm{N}$, and quinoid ring $\mathrm{C}=\mathrm{N}$ at wavelengths $1566.20 \mathrm{~cm}^{-1}, 1479.40 \mathrm{~cm}^{-1}, 1300.02 \mathrm{~cm}^{-1}$, and $1141.86 \mathrm{~cm}^{-1}$. PANI-Microcellulose composite morphology showed that PANI had been dispersed on microcellulose and free from impurities. The degrees of crystallinity are $30.9343 \%$ for microcellulose and $14.6079 \%$ for PANImicrocellulose. The optimum conductivity value of PANI-microcellulose composite at a ratio of 1:10 is 0.036013 $\mathrm{S} / \mathrm{cm}$; the electrical voltage is 1.34 volts with an electric current of $83 \mathrm{~mA}$.
\end{abstract}

Keywords: Composite, conductivity, microcellulose, Polyaniline, sonication.

\begin{abstract}
ABSTRAK
SINTESIS KOMPOSIT POLIANILIN MIKROSELULOSA. Pada penelitian ini diproduksi komposit PolianilinMikroselulosa sebagai elektrolit padat. Penelitian sebelumnya telah dilakukan sintesis komposit polianilinSelulosa. Namun nilai elektronegativitas dan tegangan listrik masih dibawah nilai baterai konvensional, sehingga untuk meningkatkan nilai tersebut dilakukan sintesis komposit Polianilin-Mikroselulosa. Tujuan utama penelitian ini adalah untuk mengetahui pengaruh komposit Polianilin-Mikroselulosa terhadap nilai konduktivitas dan nilai tegangan listriknya. Sintesis mikroselulosa menggunakan kombinasi metode hidrolisis asam sulfat dengan konsentrasi 30\%-64\% dan sonikasi. Sintesis komposit. Polianilin - Mikroselulosa dengan polimerisasi anilin secara oksidasi kimia dan sonikasi. Mikroselulosa dikarakterisasi dengan PSA. Mikroselulosa dan komposit PANI-Mikroselulosa dikarakterisasi menggunakan FTIR, SEM-EDX, dan XRD. Komposit PANI-Mikroselulosa diukur nilai konduktivitas dan besaran listriknya berturut-turut menggunakan LCR-meter dan Multimeter Digital. Diameter partikel dari mikroselulosa 20 nm-40.6 $\mu \mathrm{m}$. Mikroselulosa dan komposit PANI-Mikroselulosa menunjukan adanya pita serapan yang identik yaitu terdapat vibrasi ulur terhadap $-\mathrm{OH}$ dan $\mathrm{C}-\mathrm{H}$ (alifatik) yang ditunjukan pada panjang gelombang $3444.87 \mathrm{~cm}^{-1}, 2897.08 \mathrm{~cm}^{-1}$ yang merupakan dua gugus khas dari selulosa. Gugus khas dari PANI yaitu vibrasi tekuk dari $\mathrm{N}-\mathrm{H}$, vibrasi ulur $\mathrm{C}=\mathrm{C}, \mathrm{C}-\mathrm{N}$ dan $\mathrm{C}=\mathrm{N}$ cincin kuinoid yang terdapat pada panjang gelombang $1566.20 \mathrm{~cm}^{-1}, 1479.40 \mathrm{~cm}^{-1}, 1300.02 \mathrm{~cm}^{-1}, 1141.86 \mathrm{~cm}^{-1}$. Morfologi komposit PANIMikroselulosa menunjukan PANI sudah terdispersi terhadap mikroselulosa dan bebas dari pengotor. Derajat kristalinitas mikroselulosa 30.9343\% dan PANI-Mikroselulosa 14.6079\%. Nilai konduktivitas optimum komposit PANI-Mikroselulosa pada perbandingan 1:10 yaitu 0,036013 S/cm, tegangan listrik 1.34 volt dengan arus listrik $83 m A$.
\end{abstract}

Kata kunci: Komposit, konduktivitas, mikroselulosa, polyanilin, sonikasi. 


\section{INTRODUCTION}

The development of solid electrolytes currently uses inorganic materials, but it becomes a big problem because it cannot be processed naturally. Therefore, the material that has been developed is organic polymer material, namely polyaniline (PANI). PANI is one of the polymers that is often used because it has a high conductivity value and easily synthesized ( $\mathrm{Li}$ et al., 2010). Polyaniline has the disadvantage of rigid material properties (William et al., 2014). To overcome the rigidness of polyaniline, a composite process was carried out using a microcellulose matrix (Adriani et al., 2013), because microcellulose has better and stronger mechanical properties as well as lower molecular weights than cellulose (Yani et al., 2017).

Synthesis of microcellulose commonly used is the hydrolysis of strong acids and sonication, because strong acids are able to chained, the isolation of microcellulose can remove the amorphous part of a cellulose (Oke, 2010). Composite processes to obtain high conductivity values included sonication treatment (Sitorus et al., 2011). The sonication treatment causes acid penetration in the microcellulose.

Therefore, the mixed aniline reacted better with acidified microcellulose. PANI polymerization worked optimally on the microcellulose portion, resulting in higher conductivity values (Sitorus et al., 2011). Previous research has been conducted by (Yuningsih, L. M., Mulyadi, D., \& Sari, 2018), Synthesis of PANI-cellulose composites using the sonication method resulted in an optimum conductivity value of $0.00312 \mathrm{~S} / \mathrm{cm}$, and the resulting current is $71.4 \mathrm{~mA}$ with a potential of 1.31 volts. This value is still below the conventional battery value, which is 1.5 volts.

Based on the data and research that has been done above, a research on the synthesis of PANI- microcellulose composites was carried out in 2 steps. The first step was producing the microcellulose from corncobs by acid hydrolysis and sonication, characterized by PSA, FTIR, SEM-EDX, and XRD. The second step was producing solid electrolyte composite material which was done by dispersing microcellulose with polyaniline by sonication and dopant using $\mathrm{HCl} 3 \mathrm{M}$ (Yuningsih et al., 2017). It was then characterized by FTIR, SEM-EDX, XRD, LCRMeter and Digital Multimeter.

The purpose of this research is to make Polyaniline-microcellulose because the microcellulose in the composite process can increase the conductivity value, crystallinity (Schyrr et al., 2014), surface area, and increased dispersion of composites (loelovich,
2012). The next purpose is to determine the conductivity value of the electrical quantity of PANI-Microcellulose characterization of functional groups, morphology, crystallinity, and particle size of microcellulose.

\section{MATERIALS AND METHODS}

\section{Materials}

The materials used are corn cobs obtained from food vendors in the city of Sukabumi, and then aniline (Merck), potassium dichromate (Merck), sulfuric acid 95\% (Merck), hydrochloric acid 37\% (Merck), acetone, ethanol, sodium hydroxide, sodium hypochlorite (Merck).

\section{Procedure}

\section{Isolation of Cellulose from Corn cobs}

The method use $d$ in this work was similar to (Yuningsih et al., 2017). In brief, corn cobes chopped into small sizes, washed with water until clean. Then it was dried in an oven at $60^{\circ} \mathrm{C}$ for 24 hours. Corn cobs that have been dried are turned into powder using a grinding machine. The milled powder is then filtered in a size of 60 mesh.

The first step was delignification. $400 \mathrm{ml}$ of $\mathrm{NaOH} 2 \%(\mathrm{w} / \mathrm{v})$ was added to 16 grams of corn cobs powder. The mixture was refluxed at $90^{\circ} \mathrm{C}$ for 3 hours. The second step was bleaching; the resulting pulp was put into a $1 \%$ $\mathrm{NaOCl}$ solution at $70^{\circ} \mathrm{C}$ for 1 hour. The third step was the purification process; the result of bleaching was soaked for 30 minutes in $100 \mathrm{ml}$ of $17.5 \% \mathrm{NaOH}$ solution. The cellulose obtained was washed with distilled water and ethanol. Then it was dried in an oven at $60^{\circ} \mathrm{C}$ for 24 hours.

Synthesis of Microcellulose with Acid Hydrolysis and Sonication (Zeni \& Favero, 2016).

$1 \mathrm{gram}$ of cellulose was added with 8.75 $\mathrm{ml}$ of $\mathrm{H}_{2} \mathrm{SO}_{4}$ with a concentration variation of $30 \%, 35 \%, 40 \%, 45 \%, 50 \%, 55 \%, 60 \%$, and $64 \%(\mathrm{v} / \mathrm{v})$, stirred at $45^{\circ} \mathrm{C}$ at a speed of $500 \mathrm{rpm}$ for 30 minutes. The hydrolysis reaction was stopped by adding distilled water $(1: 15 \mathrm{v} / \mathrm{v})$, and then it was left for 24 hours. The resulting solid was sonicated at $20 \mathrm{KHz}$ and amplitude of $40 \%$ for 1 hour. Then, it was dried at a temperature of $45^{\circ} \mathrm{C}$. The microcellulose was characterized by PSA, FTIR, SEM-EDX, and XRD. 
Synthesis of PANI-Microcellulose Composite with Sonication (Yuningsih, L. M., Mulyadi, D., \& Sari, 2018)

0.5 gram of microcellulose was sonicated with $75 \mathrm{ml}$ of $\mathrm{HCl} 3 \mathrm{M}$ for 1 hour. Then, aniline was added with weight ratios of microcellulose to aniline of 1:1, 1:5, 1:10, 1:15 and 1:20, and it was sonicated for 1 hour. $\mathrm{K}_{2} \mathrm{Cr}_{2} \mathrm{O}_{7}$ was dissolved into $\mathrm{HCl} 3 \mathrm{M}$. The mol comparison of $\mathrm{K}_{2} \mathrm{Cr}_{2} \mathrm{O}_{7}$ to aniline was 1:2. For 30 minutes the two solutions were mixed and stirred using a magnetic stirrer. After that, the mixture was left for 24 hours. The mixture was filtered using a Buchner funnel. The resulted composite was washed with $0.2 \mathrm{M}$ hydrochloric acid 3 times, followed by $\mathrm{C}_{3} \mathrm{H}_{6} \mathrm{O} 100 \mathrm{ml}$. The composite was then dried at $60^{\circ} \mathrm{C}$ for 24 hours.

\section{Characterization of Polyanilin-Microcellulose}

The composite was characterized with Fourier Transform Infrared (FTIR) Spectroscopy to studied chemical structure. Scanning Electron Microscopy-Energy Dispersive X-Ray (SEMEDX) Spectroscopy was used to analyzed the morphology and the composition of the specimens. Than X-Ray Diffraction was used to measure the cristallinity. The conductivity and the electric quantities specimen both using LCRMeter and Digital Multimeter.

\section{RESULTS AND DISCUSSION}

\section{Cellulose Isolation}

Based on the research results, the delignification step obtained the black filtrate because the presence of lignin was identified in the sample, hence the color of the filtrate changed from initially colorless ( $\mathrm{NaOH}$ solution) to black. The results of the bleaching step obtained white cellulose, because the presence of hypochlorite ion as active bleaching agent can degrade the remaining lignin chains. Then the results of the purification step obtained pure cellulose is $\alpha$-cellulose.

\section{Synthesis of Microcellulose by Acid Hydrolysis and Sonication.}

The synthesis of microcellulose in this study used a combination of methods between strong acid hydrolysis and sonication. The results of hydrolysis with sulfuric acid are shown in Table 1.

Table 1. Formation of microcellulose with Acid Hydrolysis Method

\begin{tabular}{|c|c|}
\hline $\begin{array}{c}\mathrm{H}_{2} \mathrm{SO}_{4} \\
\text { Concentration }\end{array}$ & Microcellulose Result \\
\hline $30 \%$ & $\begin{array}{l}\text { The Color is slight yellow, } \\
\text { Crude fibre }\end{array}$ \\
\hline $35 \%$ & $\begin{array}{l}\text { The Color is slight yellow, } \\
\text { Crude fibre }\end{array}$ \\
\hline $40 \%$ & The Color is slight yellow, Fine \\
\hline
\end{tabular}

fibre

$45 \% \quad$ The Color is beige

$50 \% \quad$ The Color is gray

$55 \% \quad$ The Color is gray

$60 \%$ The Color is black

$64 \% \quad$ The Color is black

Based on Table 1 sulfuric acid concentration from $45 \%$ to $64 \%$ cellulose colors are darker, due to burning suspension or carbonization. The optimum concentration of sulfuric acid is at $40 \%$ because the color of cellulose obtained was slight yellow and the cellulose fibers were fine.

\section{Synthesis of PANI-Microcellulose Composite with Sonication}

The interaction between microcellulose and aniline monomers in the synthesis of PANImicrocellulose composite was assisted by ultrasonic wave for 1 hour so that the aniline monomer entering the microcellulose fibers dissolved in $\mathrm{HCl}$ would form anilium ions.

Potassium dichromate $\left(\mathrm{K}_{2} \mathrm{Cr}_{2} \mathrm{O}_{7}\right)$ is an initiator in the aniline polymerization process. The result of polymerization for 24 hours was a composite mixture; some impurities which were reaction by products and residual monomers that were not finished reacting were dissolved in $0.2 \mathrm{M} \mathrm{HCl}$ and acetone (Stejskal \& Gilbert, 2002).

\section{Microcellulose PSA (Particle Size Analyzer) Measurement Analysis}

The result of PSA analysis of particle size from microcellulose was $20 \mathrm{~nm}-40.6$ with the cumulative result of particle diameter from corncobs' Microcellulose was $1561 \mathrm{~nm}$. Number Distribution of measurement result with PSA is shown in Figure 1

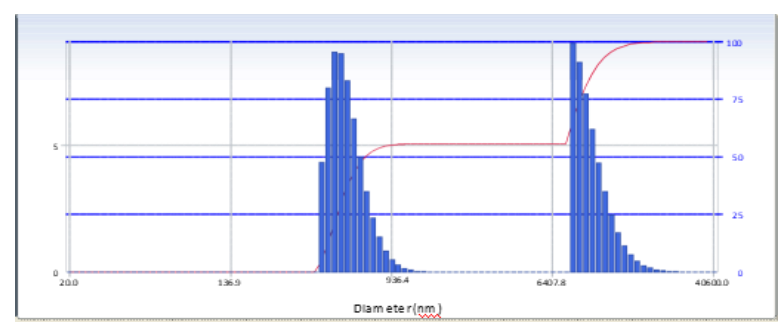

Figure 1. PSA Measurement Result Graph

Fourier Transform Infrared (FT-IR) Analysis Spectrum of Microcellulose and PANIMicrocellulose Composites.

The FTIR result spectrums of microcellulose and PANI-microcellulose composites are shown in Figure 2. 


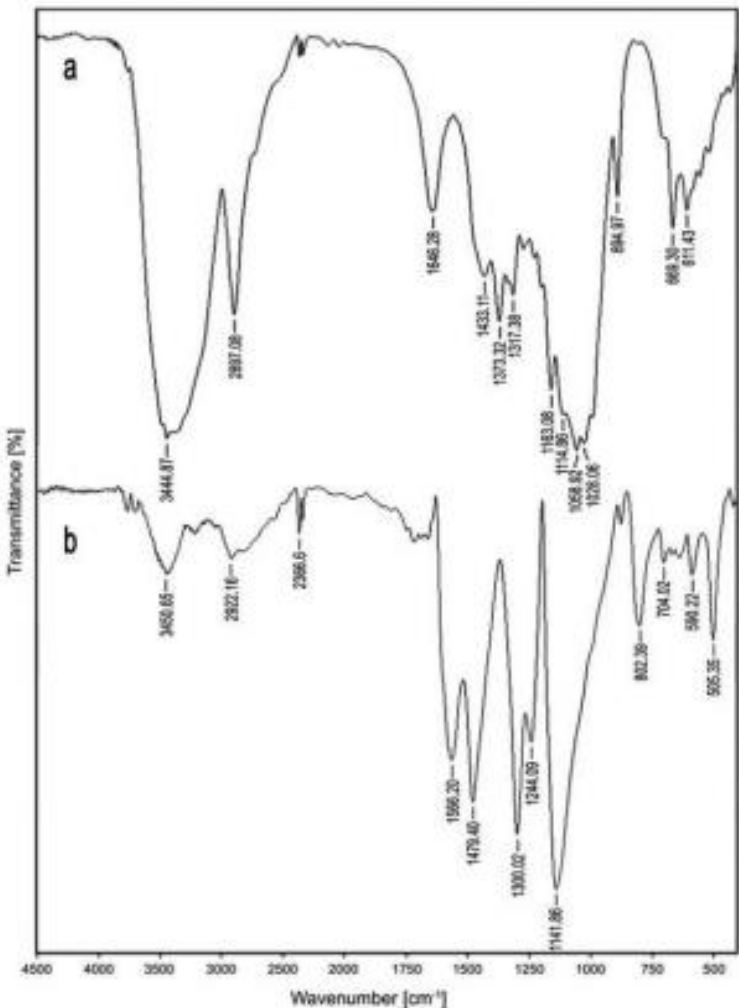

Figure 2. FTIR Spectrum (a) Microcellulose (b) PANIMicrocellulose Composites.

Based on the microcellulose spectrum, there are a stretching vibration of $-\mathrm{OH}$ and a $\mathrm{C}-\mathrm{H}$ (aliphatic) vibration indicated at the wave number $3444.87 \mathrm{~cm}^{-1}, 2897.08 \mathrm{~cm}^{-1}$. The two functional groups are typical groups of cellulose. Other groups contained in cellulose are $\mathrm{H}-\mathrm{O}-\mathrm{H}$, $\mathrm{CH}_{2}, \quad \mathrm{C}-\mathrm{H}$ (1,4 substituted by benzene) at vibrations of $1645.28 \mathrm{~cm}^{-1}, 1433.11 \mathrm{~cm}^{-1}$ and $894.97 \mathrm{~cm}^{-1}$. Then C-O-C at $1163.08 \mathrm{~cm}^{-1}$ (Mohadi et al., 2014). PANI composite FTIR results showed that there are typical peaks of polyaniline, namely wave numbers $1566.20 \mathrm{~cm}^{-1}$ , $1479.40 \mathrm{~cm}^{-1}, 1300.02 \mathrm{~cm}^{-1}$, and $1141.86 \mathrm{~cm}^{-1}$, respectively are bending vibrations from $\mathrm{N}-\mathrm{H}$, stretching vibrations from $\mathrm{C}=\mathrm{C}$ (Saikia et al., 2010), C-N stretching vibrations and quinoid ring C-N vibrations (Vollath \& Szabó, 2004).

\section{SEM-EDX (Scanning Electron Microscope- Energy Dispersive X- Ray) Analysis of the Microcellulose of PANI-Microcellulose Composites.}

The morphology and composition of microcellulose and PANI-microcellulose composites were analyzed using SEM-EDX. The results of the SEM analysis are shown in Figure 3

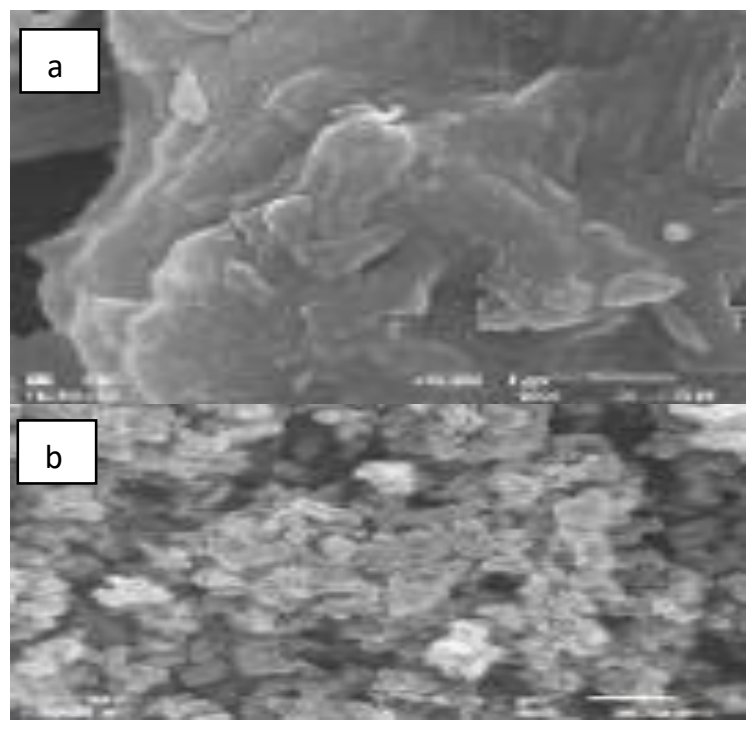

Figure 3. SEM micrograms a) Microcellulose b) PANImicrocellulose composites

Based on Figure 8, the morphology of microcellulose undergoes agglomeration one after another. Then the PANI-microcellulose composite shows the surface of the microcellulose in the form of lumps (aggregate). According to (William et al., 2014) SEM image, the synthesized polyaniline emeraldine salt (PANI-ES) has a nanocrystal structure in the form of aggregate. The occurring aggregate was caused by a relatively high stirring and was formed because it was influenced by the drying process. In the drying process, water molecules were released constantly and caused the particles to be close together to form aggregates 2.

Table 2. Composition of Microcellulose Elements and PANI-Microcellulose composites 1:10

\begin{tabular}{cll}
\hline \multicolumn{1}{c}{ Sample } & \multicolumn{1}{c}{ Element } & \multicolumn{1}{c}{$\mathrm{W} \mathrm{t} \%$} \\
\hline Microcellulose & Carbon (C) & 50.78 \\
& Oxygen (O) & 49.22 \\
PANI-Microcellulose & Carbon (C) & 81.58 \\
& Oxygen (O) & 6.24 \\
& Chlorine (Cl) & 12.19 \\
\hline
\end{tabular}

Based on the EDX results, Carbon (C) and Oxygen $(\mathrm{O})$ in microcellulose and PANImicrocellulose composites are the constituent elements of cellulose. The $\mathrm{Cl}$ element contained in the PANI-Microcellulose composite is due to the addition of $\mathrm{HCl}$ doping. Thus, based on the EDX results, microcellulose and PANImicrocellulose composite are free from impurities. 
XRD (X-Ray Diffraction) Analysis of Microcellulose and PANI-Microcellulose Composite

The diffractogram results of microcellulose and PANI-microcellulose composite are shown in Figure 4.

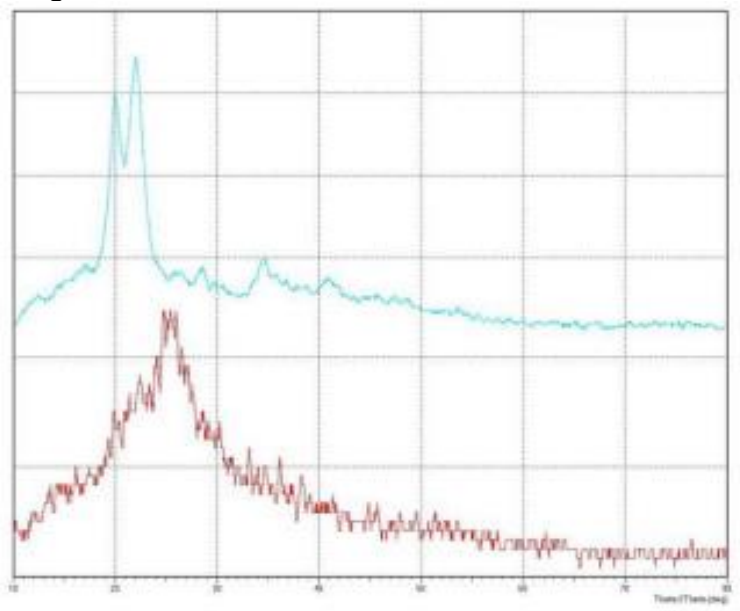

Based on Figure 4, on the microcellulose diffractogram are peaks that appear in the areas $2 \theta=22.0016^{\circ}, 20.2457^{\circ}$ and $34.5845^{\circ}$ which are the typical peaks of cellulose. The area $14-34^{\circ}$ is the typical peak of cellulose (Zhao et al., 2007). PANIMicrocellulose composite diffractogram gives typical peaks, which are in the areas $2 \theta=$ $25.5350^{\circ}$ and $22.4855^{\circ}$. Diffraction peaks $2 \theta=$ $20.42^{\circ}$ and $25.04^{\circ}$ are structural characterizations of polyaniline emeraldine (Janaki et al., 2012). So, based on XRD diffractogram, it is known that PANI has been dispersed on microcellulose.

\section{PANI-Microcellulose Composite Conductivity Values and Electrical Quantities}

PANI-Microcellulose and PANI-cellulose composite conductivity values are shown in Table 3.

Figure 4. Diffractogram of Microcellulose (Blue) and PANI-Microcellulose Composite (Red).

Table 3. Conductivity Values of PANI-cellulose Composite (Yuningsih, L. M., Mulyadi, D., \& Sari, 2018) and PANI-Microcellulose Composit

\begin{tabular}{|c|c|c|c|c|c|}
\hline \multirow[t]{2}{*}{ Composite } & \multicolumn{5}{|c|}{ Conductivity Value (S/cm) } \\
\hline & $1: 1$ & $1: 5$ & $1: 10$ & $1: 15$ & $1: 20$ \\
\hline $\begin{array}{l}\text { PANI- } \\
\text { Microcellulose }\end{array}$ & $1.9291 \times 10^{-3}$ & $1.7826 \times 10^{-2}$ & $3.6013 \times 10^{-2}$ & $5.9965 \times 10^{-3}$ & $1.0629 \times 10^{-2}$ \\
\hline PANI-Cellulose & $2.82 \times 10^{-6}$ & $1.53 \times 10^{-6}$ & $2.31 \times 10^{-3}$ & $3.12 \times 10^{-3}$ & $2.25 \times 10^{-3}$ \\
\hline
\end{tabular}

Based on the weight ratio of microcellulose to aniline, the optimum conductivity value of PANI-Microcellulose composites is at 1:10 ratio, which is $3.6013 \mathrm{x}$ $10^{-2} \mathrm{~S} / \mathrm{cm}$, producing a voltage of 1.34 volt with a current of $83 \mathrm{~mA}$, while that of PANICellulose composite is at $1: 15$ ratio, which is $3.12 \times 10^{-3} \mathrm{~S} / \mathrm{cm}$, and the electrical voltage is 1.31 volts with a current of $71.4 \mathrm{~mA}$. The conductivity value of PANI-Microcellulose composite is the highest at ratio of $1: 10$, while that of PANI-Cellulose composite is the highest at ratio of $1: 15$. This is because microcellulose is smaller than cellulose, thus, aniline added in small amounts has been completely dispersed, whereas in cellulose aniline added must be in large amounts to be completely dispersed.
The conductivity values and electrical quantities of PANI-microcellulose composite are greater than those of PANI-cellulose composite, because a material with smaller particle size will provide greater volume and surface area, so polyaniline sticks a lot in microcellulose, and results in greater conductivity values (Abdullah et al., 2008). 


\section{CONCLUSION}

Based on the research results, the corncobs' microcellulose particle diameters are between $20 \mathrm{~nm}-40.6 \mu \mathrm{m}$. The highest conductivity value is owned by PANIMicrocellulose composite with optimum conductivity value at $1: 10$ ratio, namely 3.6013 $x 10^{-2} \mathrm{~S} / \mathrm{cm}$. The functional group analysis of Microcellulose and PANI-Microcellulose composite showed identical absorption bands, namely stretching vibrations towards $-\mathrm{OH}$ and $\mathrm{C}-\mathrm{H}$ (aliphatic) shown at wavelengths 3444.87 $\mathrm{cm}^{-1}$ and $2897.08 \mathrm{~cm}^{-1}$, two typical groups of cellulose, and also typical groups of PANI, namely bending vibrations of $\mathrm{N}-\mathrm{H}$, stretching vibrations of $\mathrm{C}=\mathrm{C}, \mathrm{C}-\mathrm{N}$ and quinoid ring $\mathrm{C}-\mathrm{N}$ located at wavelengths $1566.20 \mathrm{~cm}^{-1}, 1479.40$ $\mathrm{cm}^{-1}, 1300.02 \mathrm{~cm}^{-1}$, and $1141.86 \mathrm{~cm}^{-1}$. The morphology of PANI-Microcellulose composite showed that PANI has been dispersed and free from impurities. The degrees of crystallinity are $30.9343 \%$ for microcellulose and $14.6079 \%$ for PANI-microcellulose.

\section{REFFERENCE}

Abdullah, M., Virgus, Y., Nirmin, \& Khairurrijal. (2008). Review: Sintesis Nanomaterial. Jurnal Nanosains \& Nanoteknologi, 1(2), 33-57.

Adriani, D. M., Sitorus, B., \& Destiarti, L. (2013). Sintesis Material Konduktif Komposit Polianilin-Selulosa Dari Tanah Gambut. Jkk, 2 (3)(3), 127-132.

loelovich, M. (2012). Optimal Conditions for Isolation of Nanocrystalline Cellulose Particles. Nanoscience and Nanotechnology, 2(2), 9-13. https://doi.org/10.5923/j.nn.20120202.03

Janaki, V., Vijayaraghavan, K., Oh, B. T., Lee, K. J., Muthuchelian, K., Ramasamy, A. K., \& Kamala-Kannan, S. (2012). Starch/polyaniline nanocomposite for enhanced removal of reactive dyes from syntheticeffluent. Carbohydrate Polymers, 90(4),1437-1444. https: //doi.org/10.1016/j.carbpol.2012.07.012

Li, J., Qian, X., Wang, L., \& An, X. (2010). XPS characterization and percolation behavior of polyaniline-coated conductive paper. BioResources, 5(2), 712-726.

tps://doi.org/10.15376/biores.5.2.712-726

Mohadi, R., Saputra, A., Hidayati, N., \& Lesbani, A. (2014). Studi Interaksi Ion Logam Mn2+ Dengan Selulosa Dari Serbuk Kayu. Jurnal Kimia, 8(1), 1-8.

Oke, I. (2010). Nanoscience in nature: cellulose nanocrystals. SURG Journal, 3(2),

77-80. https://doi.org/10.21083/surg.v3i2.1132

Schyrr, B., Pasche, S., Voirin, G., Weder, C., Simon, Y. C., \& Foster, E. J. (2014). Biosensors based on porous cellulose nanocrystal-poly(vinyl alcohol) scaffolds. ACS Applied Materials and Interfaces, 6(15), 12674-12683. https://doi.org/10.1021/am502670u

Sitorus, B., Suendo, V., \& Hidayat, F. (2011). Sintesis Polimer Konduktif sebagai Bahan Baku untuk Perangkat Penyimpan Energi Listrik. Jurnal ELKHA, 3(1),43-47.

Stejskal, J., \& Gilbert, R. G. (2002). Polyaniline. Preparation of a conducting polymer (IUPAC technical report). Pure and Applied Chemistry, 74(5), 857-867. https://doi.org/10.1351/pac20027405085

Vollath, D., \& Szabó, D. V. (2004). Synthesis and Properties of Nanocomposites. Advanced Engineering Materials, 6(3), 117-127. https://doi.org/10.1002/adem.200300568

William, R. A., Sitorus, B., \& Malino, M. B. (2014). Sintesis Polianilin Pada Matriks Selulosa Sebagai Elektrolit Padat Pada Model Baterai Sederhana. Jkk, 3(4), 3238.

Yani, R., Purwaningsih, H., \& Mas'ud, Z. A. (2017). Mikroselulosa Nata de Coco sebagai Bahan Baku Hydroxypropyl Methylcellulose(HPMC).[Institut

Pertanian Bogor]. http://repository.ipb.ac.id/handle/123456 $789 / 83593$

Yuningsih, L. M., Mulyadi, D., \& Sari, H. A. (2018). Effect of Swelling and Sonication Methods on Conductivity of PolyanilineCellulose from Corn Cob ( Zea mays L .). International Journal of Applied Chemistry, 14(4), 281-292.

Yuningsih, L. M., Mulyadi, D., \& Aripandi, I. (2017). Effect of Various Dopant HCL Concentration on Electrical Conductivity of Pani-Cellulose Composite with Cellulose Isolated from Reed Plant (Imperatacy lindrica (L.)). American Journal of Materials Science, 2017(3), 59-63. https://doi.org/10.5923/ j.materials. 20170703.03

Zeni, M., \& Favero, D. (2016). Preparation of Microcellulose (Mcc) and Nanocellulose (Ncc) from Eucalyptus Kraft Ssp Pulp. Polymer Science, 1(1), 1-5. https://doi.org/10.4172/24719935.100007

Zhao, H., Kwak, J. H., Conrad Zhang, Z., Brown, H. M., Arey, B. W., \& Holladay, J. E. (2007). Studying cellulose fiber structure by SEM, XRD, NMR and acid hydrolysis. Carbohydrate Polymers, 68(2), 235-241. https://doi.org/10.1016/j.carbpol.2006.12. 